\begin{tabular}{|l|l|l|l|l|l}
\hline Int.J.Curr.Microbiol.App.Sci (2018) 7(10): 1016-1024 \\
$\begin{array}{l}\text { International Journal of Current Microbiology and Applied Sciences } \\
\text { ISSN: 2319-7706 Volume 7 Number 10 (2018) } \\
\text { Journal homepage: http://www.ijcmas.com }\end{array}$ \\
\hline $\begin{array}{l}\text { EXCELLENT } \\
\text { PUBLISHERS }\end{array}$
\end{tabular}

\title{
Impact Analysis of Micro Irrigation System (MIS) on Yield, Water, Fertilizer Saving and Farmer's Economy
}

\author{
Ram Vaibhav ${ }^{1}$ and D. Makwana Ajay ${ }^{2 *}$ \\ ${ }^{1} S R F$, Agri-CRP, ICAR-CSSRI, RRS, Opposite Jyotinagar water tank, Zadeswar road, \\ Bharuch, Gujarat - 392012, India \\ ${ }^{2}$ Department of Agri. Engg. Parul University, ICAR-CSSRI, RRS, Opposite Jyotinagar water \\ tank, Zadeswar road, Bharuch, Gujarat-392012, India \\ *Corresponding author
}

\begin{abstract}
A B S T R A C T
A case study was conducted on evaluation of MIS and traditional irrigation methods on the farmer's prospective with an aim to develop understanding about potential benefits of drip

Keywords

Micro-irrigation, $\mathrm{BC}$ ratio, Water saving, MIS

Article Info

Accepted: 10 September 2018 Available Online: 10 October 2018 irrigation system among farming community of the Kodinar and near Taluka of Gujarat. Comparative assessment in terms of yield gain, water productivity and net returns was carried out for wheat, bajra, groundnut, sugarcane, cotton and mango. About 70 farmers field who were using drip irrigation for more than 3 consecutive years from 2013 covering an area of around 210 hectare was taken for the study. The study revealed that, for the selected crop which adopted drip irrigation improved the yields in the range of 14.59 to $81.9 \%$ over traditional irrigation with highest yield increase in case of mango $(81.9 \%)$ and wheat $(14.59 \%)$. Drip irrigation consistently recorded higher water productivity (WP) with more than five folds increase in case of mango. The average WP was higher under drip irrigation $\left(5.43 \mathrm{~kg} \mathrm{~m}^{-3}\right)$ as compared to traditional method $\left(0.94 \mathrm{~kg} \mathrm{~m}^{-3}\right)$. Economic analysis revealed that the average benefit-cost (CB) ratio of all drip irrigated crops was about 3.113. Among all the crops drip irrigated Sugarcane was found to be the most remunerative crop with higher net returns $(2,44,220 \mathrm{Rs} / \mathrm{ha})$ and highest $\mathrm{BC}$ ratio of 4.83 .
\end{abstract}

\section{Introduction}

This study is about impact analysis of Micro irrigation system compare to traditional method on farming community of this region.

This is a study about farmer's who used Micro irrigation without any technical knowledge of it, and even though MIS is beneficiary or not. Mainly water and economic aspect cover in this paper.
Case study has carried out with the help of ACF (Ambuja Cement Foundation). ACF is a corporate NGO which is working in Kodinar, Sutrapada, and some part of Una and Talala taluka of Gujrat. It was established in 1992. The Foundation is a development organisation committed to engaging the rural communities in and around Ambuja Cements Ltd's (ACL) manufacturing locations. ACF adds value to the lives of the people through its process of engagement. The foundation undertakes 
program and projects on developmental issues in line with needs of people in partnership with them. These developmental initiatives are undertaken through meaningful involvement either with like-minded NGOs or with the Government. Foundation has presence in 22 locations in 11 states of India with direct benefited to more than 20 lakh populations in 771 villages.

Kodinar and neighboring talus's farmers are benefited by ACF through many type of scheme, which is helped them economically in farming. Study region comes under semi-arid agro climatic Zone, so water shortage in irrigation is happens many time in past. Sugarcane and cotton are the main harvesting crops of this area.

Micro irrigation System (MIS) mainly drip irrigation system become popular in farmers' community in resent future, Gov. of Gujarat give subsidy to farmers for MIS to promoting it, ACF give additional subsidies directly to the framers above Gov. of Gujarat since 2009 whatever villages come under its criteria. Up to 2013 nearly about 2005.65ha area in different crop has subsidies by ACF (ACF Annual report 2007-08). ACF wants to find whatever subsidies provided to farmers whether it is improved livelihood of farmer or not.

Impact analysis of MIS adopted and appropriately utilized by farmer in terms of water saving, fertilizer, pesticide and yield increase has mention in this study. For this case study more than 70 farmers' irrigation method analysis and farming practices for a different crop, and collect information of year by year yield for different crop. In this study farmer choose on the biases of who used MIS properly for at least last 3 year and more, total 210 ha area has covered in this study and crop are Cotton, groundnut, Wheat, Bajra, Sugarcane and Mango.
Many study about MIS has down in past. And every study shows that highlights the need to adopt modern efficient irrigation method of drip which offers several advantages over furrow irrigation including higher water and fertilizer use efficiency and high yield (Camp et al., 2001). Many studies shows that adoption of MIS improved the yields in the range of 38.2 to $65.8 \%$ over traditional irrigation and The average Water Productivity was higher under drip irrigation $\left(6.89 \mathrm{~kg} \mathrm{~m}^{-3}\right)$ as compared to traditional method $(1.31 \mathrm{~kg}$ $\mathrm{m}^{-3}$ ). Economic analysis revealed that the average cost-benefit (CB) ratio of all MIS crops was about $33 \%$ higher over furrow method of water application (Jha et al., 2017).

\section{Objectives}

The objectives of the study are: to research the farming practices adjust related to MIS adoption in Kodinar and nearby talukas; and to evaluate the economic and social benefits of micro irrigation adoption within the area.

\section{Materials and Methods}

The study was conducted in the Kodinar, Talala, Sutrapada and Una taluka of Junagadh District of Gujarat, India, where drip irrigation system is promoted by Ambuja Cement Foundation for economic benefit of farmers. Two type of farmers were selected so as to represent drip adoption and control (without drip). From the selected villages, some villages were selected purposely where the adoption of drip irrigation is more and taken up for more than 3 year or at least one crop taken by drip system per year.

To analyze the adoption and effect of micro irrigation on useful resource use, agricultural manufacturing and farm economic gain, some MIS adopting farmers have been selected in each village and correspondingly some nonadopters were decided on in equal villages. To short the MIS adopters, the list of farmers 
from the ACF turned into accrued. Additionally, we enumerated the list of farmers adopting drip irrigation after discussions with the villagers and private companies dealing drip irrigation structures. Thus, a sample of $70+$ farmer from 22 village were studied.

\section{Data collection and analysis}

Framer's specific information accumulation sheets were designed to record the manpower and other inputs used throughout the cropping season. Framer and crop wise data on labor requirement and other expenditures on land preparation (plowing, harrowing, bed preparation), plant protection measures, irrigation, staking, harvesting etc. was recorded in the designed sheets. Cost of drip irrigation system was recollected from local company's dealer, who install drip on particular farmer's field. Without any government and ACF subsidy. Market prices of the selected drip and crop were recorded for entire harvesting period to estimate the gross returns. Annual cost of growing crops under drip was calculated by considering depreciation, components' life, annual interest. For annual cost of drip irrigation system, running life of drip irrigation components i.e., main and sub main line, fertilizer assembly, laterals with inline emitters, venturi assembly and filters was considered as 10 years.

\section{Water usage analysis}

To find out water saving in MIS (drip), water usage in drip and without drip has estimated. Based on information collected from farmers irrigation scheduling like numbers of irrigation, time taken per irrigation and area irrigated per day in both method of irrigation total amount used in each method and crop wise noted.
Water saving was studied by dividing Annual Irrigation schedule into 3 quarter with four months each and calculating the total amount of water used in drip and without drip quarterwise.

In Drip LPH of dripper and number of dripper per valve is important parameter of the system to find out water discharge each time. Form irrigation point of view every crop have four stages initial stage (sowing to germination), growth stage (germination to pick of vegetative growth), Mid-season stage (pick of vegetative growth to seed produce), late season stage (after seed produce). In first stage amount of water apply per day is constant, second stage it is gradually growing day by day, in third stage it is highest of the season and constant every day. In fourth stage gradually it will decreased. In farmer's information accumulation sheets it was mansion in detail. Likewise weeding schedule and pesticides also calculated in both conditions (with and without drip) (Michael, 1997).

\section{Benefit cost ratio}

$\mathrm{BC}$ ratio is the benefit increase due to extra money invested in MIS by farmers. Initial investment in MIS is more, but suddenly it has benefited in labor input, fertilizer, and intercultural operation. So all over net return start from first year but it will increase year by year. The Benefits Cost Analysis was calculated by the following equation.

Annual cost of drip irrigation system (Michael et al., 2008)

A.C $=\frac{\frac{p \times i \times(1+i)^{n}}{(1+i)^{n}-1}}{(10)}$

Where,

A.C $=$ annul cost, 
$\mathrm{p}=$ Total Cost of drip (farmer contribution +all subsidy),

${ }^{i}=$ present of interest $(10 \%)$,

$n=$ life of drip (10 year)

\section{Assessment of WP (water productivity)}

Water productivity in irrigation can be defined two way; in terms of Yield generateper unit of water utilized or economic gain per unit of water utilized.

The irrigation water productivity could be estimated either in relation to measure of water applied, it's applied water productivity or the measure of water consumed by the crop (it's productivity of consumed water ET) or the total amount of water applied, i.e., irrigation plus the excess rainfall (Kijne et al., 2003).

\section{Results and Discussion}

Water saving per ha in terms of $\mathrm{m}^{3} / \mathrm{Ha}$ are shown in figure 1, Maximum amount of water was saved in sugarcane $\left(6195 \mathrm{~m}^{3} / \mathrm{Ha}\right)$ followed by cotton, mango, wheat, bajra and groundnut. But percentage wise water saving was more in mango with $64 \%$ followed by sugarcane $(46 \%)$, bajra $(38 \%)$, groundnut and cotton (37\%) and wheat (29\%) (Table 1 and 2).

Reduction in cost of weeding operation under different crop has been shown in figure 2 . Highest cost saving was in mango (86\%) followed by sugarcane (58\%), Bajra (56\%), wheat (45\%), groundnut (43\%) and cotton (39\%).

Cost of fertilizer also decreased and it is shown in figure 3. Highest cost saving was in cotton $(51 \%)$ followed by bajra $(40 \%)$, sugarcane $(37 \%)$, mango (13\%), but there was no effect on wheat and groundnut (Table 3 ).

Cost of MIS has been distributed per year for 10 year considering its life span of 10 years. Cost of MIS was less in horticulture crop due higher lateral spacing crop since to price of lateral pipe is nearly about $50 \%$ of MIS cost. So cost of cultivation directly benefited with MIS application rather than traditional method. Only wheat, groundnut and bajra had higher value of MIS+ Cultivation cost. But increment in Net profit was observed in all the crops. Extra cost added in form of MIS by Net profit increment is Cost Benefit ratio (BC). In all the crops $\mathrm{BC}$ ratio was positive. Highest $\mathrm{BC}$ ratio was observed in Sugarcane and Mango and lowest in bajra (Table 4).

Table.1 Without drip water usage

\begin{tabular}{|l|l|l|l|l|l|l|l|}
$\begin{array}{l}\text { Quarter } \\
\text { (4 Month } \\
\text { each) }\end{array}$ & $\begin{array}{l}\text { No of } \\
\text { irrigation }\end{array}$ & $\begin{array}{l}\text { Discharge } \\
\text { of Mortar }\end{array}$ & $\begin{array}{l}\text { Area } \\
\text { irrigated }\end{array}$ & $\begin{array}{l}\text { Time }(\mathrm{Hr} / \\
\text { Irrigation) }\end{array}$ & $\begin{array}{l}\text { volume } \\
(\mathbf{m 3})\end{array}$ & $\begin{array}{l}\text { Vol./ } \\
\text { season }\end{array}$ & $\begin{array}{l}\text { Vol. } \\
\text { / Ha }\end{array}$ \\
\hline $\mathbf{1}$ & N1 & Q1 & A1 & X & $\begin{array}{l}\text { v1=N1*Q1* } \\
3600 * \mathrm{X}\end{array}$ & $\begin{array}{l}\text { V= } \\
\text { v1+v2+ }\end{array}$ & $\begin{array}{l}\text { V/ } \\
\text { (A1, } \\
\text { A2, } \\
\text { A3) }\end{array}$ \\
\hline $\mathbf{2}$ & N2 & Q2 & A2 & Y & $\begin{array}{l}\text { v2=N2*Q2* } \\
3600 * Y\end{array}$ & & \\
\hline $\mathbf{3}$ & N3 & Q3 & A3 & Z & $\begin{array}{l}\text { v3=N3*Q3* } \\
3600 * Z\end{array}$ & & \\
\hline
\end{tabular}


Table.2 With drip water usage

\begin{tabular}{|c|c|c|c|c|c|c|c|}
\hline $\begin{array}{l}\text { Quarter } \\
\text { (4Mont } \\
\text { h each) }\end{array}$ & $\begin{array}{l}\text { Time/ } \\
\text { Day } \\
\text { (hr) }\end{array}$ & $\begin{array}{l}\text { No of } \\
\text { Valve }\end{array}$ & $\begin{array}{l}\text { Dripper } \\
\text { /Valve }\end{array}$ & $\begin{array}{l}\text { Lph of } \\
\text { dripper } \\
\text { (L) }\end{array}$ & Volume (m3) & $\begin{array}{l}\text { Volume/ } \\
\text { Season }\end{array}$ & $\begin{array}{l}\text { Volume } \\
\text { / ha }\end{array}$ \\
\hline 1 & $X$ & N1 & D1 & L1 & $\begin{array}{c}\mathrm{V} 1=\mathrm{X} * \mathrm{~N} 1 * \\
(\mathrm{~L} 1 / 1000) * \mathrm{D} 1\end{array}$ & \multirow[t]{3}{*}{$\mathrm{V}=1+2+3$} & \multirow[t]{3}{*}{ V/ha } \\
\hline 2 & Y & $\mathrm{N} 2$ & D2 & L2 & $\begin{array}{c}\mathrm{V} 1=\mathrm{Y} * \mathrm{~N} 2 * \\
(\mathrm{~L} 2 / 1000) * \mathrm{D} 2\end{array}$ & & \\
\hline 3 & $\mathrm{Z}$ & N3 & D3 & L3 & $\begin{array}{c}\mathrm{V} 1=\mathrm{Z} * \mathrm{~N} 3 * \\
(\mathrm{~L} 3 / 1000) * \mathrm{D} 3\end{array}$ & & \\
\hline
\end{tabular}

Table.3 Calculate all cost which is paid by farmer per $\mathrm{Ha} /$ year

\begin{tabular}{|c|c|c|}
\hline Type of Cost & Drip & Without drip \\
\hline Cost Drip/year & \multirow[t]{2}{*}{$\mathrm{D} 1+\mathrm{D} 2$} & \multirow[t]{2}{*}{0} \\
\hline fitting cost & & \\
\hline Acid treatment & D3 & 0 \\
\hline Packing of latter cost & D4 & 0 \\
\hline Irrigation Cost & 0 & WD1 \\
\hline Intercultural operation & D5 & WD2 \\
\hline Tillage cost & D6 & WD3 \\
\hline Weeding Cost & D7 & WD4 \\
\hline Fertilizer Cost & D8 & WD5 \\
\hline Pesticide Cost & D9 & WD6 \\
\hline Seed Cost & D10 & WD7 \\
\hline Furrow Cost & D11 & WD8 \\
\hline Sowing Cost & D12 & WD9 \\
\hline Harvesting cost & D13 & WD10 \\
\hline Total Cost & $\mathrm{TDC}=\Sigma \mathrm{D}(1-13)$ & $\mathrm{TCWD}=\Sigma W D(1-10)$ \\
\hline Net yield(Rs) & DNY & WDNY \\
\hline Net Profit (Rs) & DNY-TCD & WDNY-TCWD \\
\hline Profit Increment & $\multicolumn{2}{|c|}{$ DNY-TCD }$-\{$ WDNY-TCWD $\}$ \\
\hline $\mathrm{BC}$ ratio & \multicolumn{2}{|c|}{ Profit Increment/\{D1+D2\} } \\
\hline
\end{tabular}


Table.4 Cost of MIS, Cultivation and CB ratio per Ha basis

\begin{tabular}{|c|c|c|c|c|c|c|}
\hline \multirow[t]{2}{*}{ Crop } & \multirow{2}{*}{$\begin{array}{c}\text { Cost of } \\
\text { MIS/ha/year }\end{array}$} & \multicolumn{2}{|c|}{ Cost of cultivation } & \multirow{2}{*}{$\begin{array}{c}\text { MIS+ } \\
\text { cultivation }\end{array}$} & \multirow{2}{*}{$\begin{array}{c}\text { Profit } \\
\text { Increase }\end{array}$} & \multirow{2}{*}{$\begin{array}{c}\text { CB } \\
\text { ratio }\end{array}$} \\
\hline & & MIS & without MIS & & & \\
\hline Sugarcane & 21285 & 32477 & 63647 & 53762 & 102851 & 4.83 \\
\hline Cotton & 26791 & 42736 & 73303 & 69527 & 59302 & 2.21 \\
\hline Wheat & 21178 & 28500 & 49420 & 49678 & 35640 & 1.68 \\
\hline Groundnut & 11156 & 39550 & 47891 & 50707 & 46410 & 4.16 \\
\hline Mango & 13046 & 13717 & 30743 & 26763 & 61045 & 4.68 \\
\hline Bajara & 25153 & 19673 & 31895 & 44826 & 28222 & 1.12 \\
\hline
\end{tabular}

Source: Field survey during 2013

Table.5 Yield and water productivity of crops under MIS and Without MIS

\begin{tabular}{|c|c|c|c|c|c|c|}
\hline \multirow[t]{2}{*}{ Crop } & \multicolumn{2}{|c|}{$\operatorname{Yield}(q / H a)$} & \multirow{2}{*}{$\begin{array}{l}\text { Percent } \\
\text { Yield } \\
\text { increase }\end{array}$} & \multicolumn{2}{|c|}{$\begin{array}{l}\text { Water productivity } \\
(\mathrm{Kg} / \mathrm{m} 3)\end{array}$} & \multirow{2}{*}{$\begin{array}{c}\text { Percent Water } \\
\text { productivity } \\
\text { increase }(\%)\end{array}$} \\
\hline & MIS & $\begin{array}{l}\text { Without } \\
\text { MIS }\end{array}$ & & MIS & $\begin{array}{l}\text { Without } \\
\text { MIS }\end{array}$ & \\
\hline sugarcane & 1221.1 & 862.7 & 41.5 & 16.76 & 6.40 & 162 \\
\hline cotton & 42.4 & 36.7 & 15.7 & 0.63 & 0.35 & 81 \\
\hline Wheat & 58.4 & 51.0 & 14.4 & 1.32 & 0.79 & 68 \\
\hline Groundnut & 26.3 & 18.6 & 40.8 & 1.26 & 0.55 & 129 \\
\hline Mango & 67.2 & 36.9 & 81.9 & 5.44 & 0.95 & 475 \\
\hline Bajara & 50.0 & 40.0 & 25.0 & 2.23 & 1.11 & 102 \\
\hline
\end{tabular}

Source: Field survey during 2013

Fig.1 Water use and saving $\left(\mathrm{M}^{3} / \mathrm{Ha}\right)$

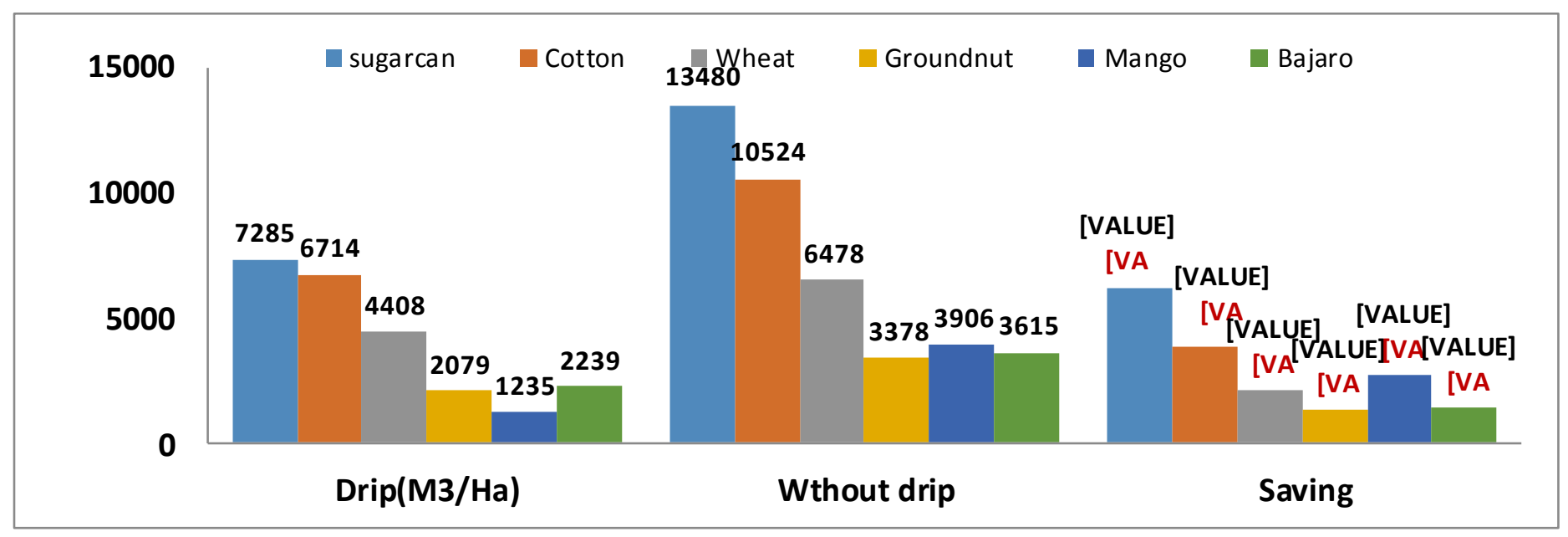


Fig.2 Cost of weeding (Rs/Ha)

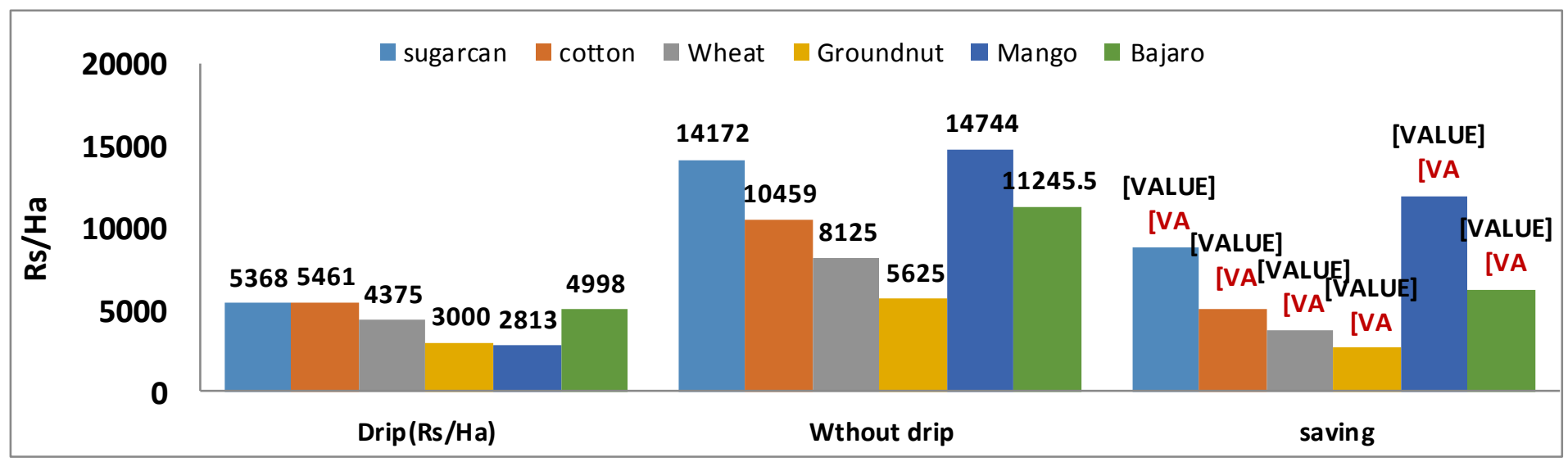

Fig.3 Cost of Fertilizer (Rs/Ha)

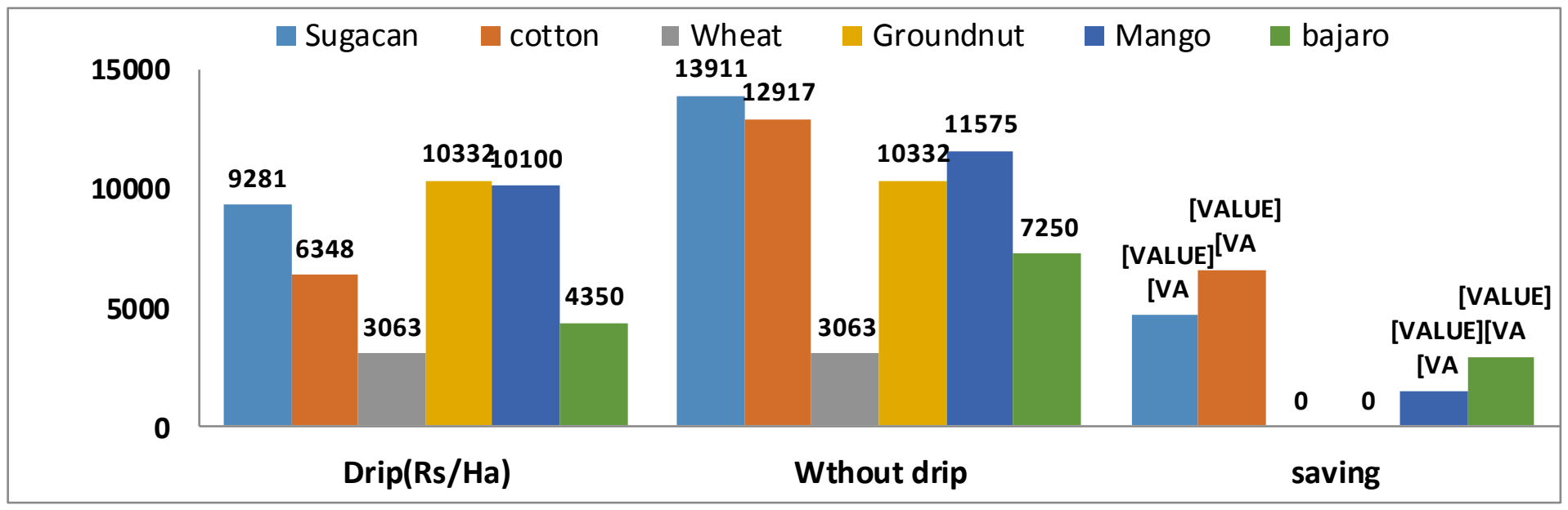

\section{Yield and water productivity}

Results of the yield and water productivity of different crops as obtained under drip and traditional method of water application are presented in Table 5. The results revealed that yields of all crops were higher when water was applied through drip irrigation. Maximum yield of $1221.1 \mathrm{q} \mathrm{ha}^{-1}$ was recorded for drip irrigated sugarcane. The percent increase in the yields over conventional irrigation system was found highest in mango
(81.9\%) followed by sugarcane (41.5\%), Groundnut (40.8\%), Bajara (25\%), cotton $(15.7 \%)$ and Wheat (14.4\%). Average WP of all crops under MIS and traditional method was 4.61 and $1.69 \mathrm{~kg} / \mathrm{m} 3$, respectively. The percent increase in WP over conventional irrigation system was found highest WP observed in mango (475\%) followed by sugarcane (162 \%), Groundnut (129\%), Bajara (102\%), cotton (81\%) and Wheat $(68 \%)$. 
Previous studies on the impact of drip irrigation on water and fertilizer saving and weed competition found that drip irrigation had desired positive impacts compared to surface irrigation (Dhawan et al., 2002; Kulecho et al., 2005; Magar et al., 1988; Namara et al., 2005; Narayanamoorthy 2003 \& 2006; Verma et al., 2004; Qureshi et al., 2001). It is mansion and proves by many researchers that micro irrigation system is technically and economically feasible, particularly when the farmers' mainly depend on groundwater sources for irrigation (Dhawan, 2000).

Micro-irrigation system had a positive effect on crop production with regard to water saving, fertilizer saving and reducing weed competition. The MIS improved the economic status of farmers in Kodinar region. MIS is a cost effective and technically feasible method which can be promoted for increasing crop productivity and profitability of farmers.

\section{Acknowledgement}

We are especially thankful to Er. Dungarani, Er. Vaghasiya and ACF team who gave funding and golden opportunity to completed this research work on the Impact analysis of Micro Irrigation System (MIS) on Yield, water, fertilizer saving and farmer's economy, which also helped us in doing a lot of work in the research area and also to know about many new things in this particular research. Secondly we are also thankful to Er. Solanki, Er. Barad and farmers (Kodinar, Una \&amp; Sutrapada district) who helped us a lot in finalizing this research.

\section{References}

ACF. Annual report 2007-08. Ambuja cement foundation, Ambujanagar, Veraval road, kodinar-02795: (2013).
Camp, C. R., E. J. Sadler, W. J. Busscher, R. E. Sojlka and D. L. Karrlin. Experiencing with sprinkler irrigation for agronomic crops in the southeastern USA: (2001).

Dhawan, B. D. Technological Change in Irrigated Agriculture: A Study of Water Saving Methods. Commonwealth Publishers, New Delhi: (2002)

Dhawan, B.D. Drip irrigation: Evaluating returns, Economic and Political Weekly, 35(42): 3775-3780: (2000).

Jha B. K., Mali S. S., Naik S. K. And Sengupta T, yield, water productivity and economics of vegetable production under drip and furrow irrigation in eastern plateau and hill region of India, International Journal of Agricultural, 7(3): 43-50: (2017).

Kijne, J., Barker R. and D. Molden, Improving Water Productivity in Agriculture: Editors' Overview, in Jacob Kijne (Eds.) Water Productivity in Agriculture: Limits and Opportunities for Improvement, Comprehensive Assessment of Water Management in Agriculture. UK: CABI Publishing in Association with International Water Management Institute: (2003).

Kulecho, I.K. and Weatherhead, E.K. Reasons for smallholder farmers discontinuing with low cost micro irrigation: A case study from Kenya, Irrigation and Drainage Systems, 19 (2): 179-188: (2005).

Magar, S. S., Firke, N. N. and Kadam, J. R. Importance of drip irrigation. Sinchan, 7 (2): 61-62: (1988).

Michael A. M., Khepar S. D., Sondhi S. K. Water Wells and Pumps, Tata McGrawHill Publishing Company Limited, New Delhi- 110 008, Page 42-43: (2008).

Michael, A.M. Irrigation: Theory and practices. Vikas Publishing House Pvt Ltd, Delhi: (1997). 
Namara, Regassa E., Upadhyay, Bhawana and Nagar, R. K. Adoption and Impacts of Microirrigation Technologies: Empirical Results from Selected Localities of Maharashtra and Gujarat States of India, International Water Management Institute, Colombo, Sri Lanka Research Report 93:(2005).

Narayanamoorthy, A. Averting water crisis by drip method of irrigation: A study of two water intensive crops, Indian Journal of Agricultural Economics, 58(3):427-437: (2003).

Narayanamoorthy, A. Economics of drip irrigation in sugarcane cultivation: Case study of a farmer from TamilNadu,
Indian Journal of Agricultural Economics, 60(2): 235-248: (2005).

Qureshi, M.E., Wegener, M.K., Harrison, S.R. and Bristow, K.L. Economic evaluation of alternate irrigation systems for sugarcane in the Burdekin delta in North Queensland, Australia, In: Water Resource Management, Eds: C.A. Brebbia, K. Anagnostopoulos, K. Katsifarakis and A.H.D. Cheng, WIT Press, Boston, pp. 47-57: (2001).

Verma, S., Tsephal, S. and Jose, T. Pepsee systems: Grass root innovation under groundwater stress. Water Policy, 6: 116: (2004).

\section{How to cite this article:}

Ram Vaibhav and Makwana Ajay, D. 2018. Impact Analysis of Micro Irrigation System (MIS) on Yield, Water, Fertilizer Saving and Farmer's Economy. Int.J.Curr.Microbiol.App.Sci. 7(10): 1016-1024. doi: https://doi.org/10.20546/ijcmas.2018.710.113 